increase in admissions to hospital during their study because patients presenting in this way are more likely to be admitted than those managed at home.

The main value of these studies is to draw attention to the disadvantages of using routine mortality and morbidity statistics or surveys of self reported asthma or reported disease by a parent to assess the true trend in the prevalence of asthma. More reliable information may be obtained by validating changes in responses to standardised questionnaires against objective assessments of the disease. One recent study that provides data of this quality showed a doubling in the prevalence of asthma reported by parents in 12 year old children over 15 years, which was associated with compatible increases in the prevalences of wheezing and exercise induced bronchoconstriction. " The more recent study by Ninan and Russell ( $p$ 873) does not include an objective validation of the reported increase in asthma prevalence but shows a doubling of self reported wheeze and the proportion of those with wheeze who report a diagnosis of asthma. Collectively these data provide evidence that, despite possible artefacts introduced by changes in recognition or labelling, the true prevalence of asthma has increased. The reporting in both studies $^{811}$ that the prevalence of hayfever and eczema had also increased substantially suggests that the increase in wheezing is part of a more general increase in the expression of atopic disease. It is now important to establish whether the same applies in other sections of the population and to begin to look for explanations.

JOHN BRITTON

Senior Lecturer in Respiratory Medicine,

Respiratory Medicine Unit,

City Hospital,

Nottingham NG5 1PB

1 Office of Health Economics. Asthma. London: Office of Health Economics, 1990. (Studies of current health problems No 95 .

Fleming DM, Crombie DL. Prevalence of asthma and hay fever in England and Wales. BMJ 1987;294:279-83.

3 Hay IFC, Higenbottam TW. Has the management of asthma improved? Lancet 1987;ii:609-11.

4 Burney PGJ, Chinn S, Rona RJ. Has the prevalence of asthma increased in children? Evidence from the national study of health and growth 1973-86. BMF 1990;300:1306-9.

Robertson CF, Heycock E, Bishop J, Nolan T, Olinsky A, Phelan PD. Prevalence of asthma in Melbourne schoolchildren: changes over 26 years. BMf 1991;302:1116-8.

6 Haahtela T, Lindholm H, Bjorksten F, Koskenvuo K, Laitinen LA. Prevalence of asthma in Finnish young men. $B M 7$ 1990;301:266-8.

Gergen PJ, Mullally DI, Evans R. National survey of prevalence of asthma among children in the United States, 1976 to 1980 . Pediatrics 1988;81:1-7.

8 Ninan TK, Russell D, Russell G. Increasing prevalence of respiratory symptoms and atopy in Aberdeen schoolchildren: evidence from two surveys. BMF 1992;304:873-5.

Strachan DP, Anderson HR. Trends in hospital admission rates for asthma in children. BMf 1992;304:819-20.

10 Hill R, Williams J, Tattersfield A, Britton J. Change in use of asthma as a diagnostic label for wheezing illness in schoolchildren. BMf 1989;299:898.

11 Burr ML, Butland BK, King S, Vaughan-Williams E. Changes in asthma prevalence: two surveys 15 years apart. Arch Dis Child 1989;64:1452-6.

\title{
Discovery of the gene for familial adenomatous polyposis
}

\author{
May also increase our understanding of sporadic colorectal cancer
}

Isolating and sequencing the gene for autosomal dominant familial adenomatous polyposis ${ }^{1-4}$ are not just a tour de force of molecular biology in a rare condition. Their significance lies in the role of the mutant gene in the common, sporadic form of colorectal carcinoma, which also arises in polyps. ${ }^{5}$ Whereas in the familial disease the abnormal gene is inherited in the germ line (and carried by every cell in the body), in at least some sporadic cancers it arises by somatic mutation in colonic epithelial cells. ${ }^{4}$

The story started with a case report of a patient with multiple developmental abnormalities and Gardner's syndrome (colonic polyposis and soft tissue tumours). ${ }^{6}$ Banding studies of the chromosomes showed a segment was missing from the long arm of chromosome 5 (5q), providing a clue for the location of the abnormal gene. DNA probes, mapping close to the deletion on $5 \mathrm{q}$, allowed the inheritance of the abnormal gene to be followed in affected families. ${ }^{7}$

In this issue MacDonald and coworkers (p 869) ${ }^{8}$ have shown that this approach can be applied to presymptomatic diagnosis. Unfortunately, as a genetic "neighbour" rather than the abnormal gene is being studied this method requires a pedigree: when the relatives have died or the disease has resulted from a new mutation (as occurs in up to $40 \%$ of cases $^{9}$ ) it cannot be used.

Why did it take from 1987, when the approximate position of the mutant gene on 5q21 was published, ${ }^{7}$ until last year to isolate and sequence the gene itself? Knowing the approximate position of the mutant gene still left a vast amount of DNA to search, - with distances in excess of 8000 kilobase (kb) pairs of DNA. (The size of the cDNA for the gene turned out to be $0.9 \mathrm{~kb} .^{23}$ )
The standard approach is to isolate a series of cloned DNA fragments from a genetic library which overlap each other, thereby allowing a continuous map of the region of interest to be built up. This is difficult unless large pieces of DNA are cloned; even then sorting out which clones contain DNA of relevant genes is not easy.

The discovery of tiny deletions of DNA from chromosome 5 in two unrelated patients with familial adenomatous polyposis provided a further lead. ${ }^{1}$ These deletions were much too small (about $260 \mathrm{~kb}$ ) to affect the banding pattern, but the deleted DNA segment common to both was presumed to contain the abnormal gene. Probes covering the DNA of the deletion were used to identify new genes within it. Three genes were found: the sequence of two of them did not match that of any previously identified gene, making them candidates for the mutant gene.

To decide whether either of these was the abnormal gene, mutations had to be found in DNA from patients with familial adenomatous polyposis but not in DNA from their unaffected relatives. As many cases of the disease probably result from a point mutation the technique of single strand confrrmation polymorphism analysis was used.

Abnormalities were found in only one of the genes. ${ }^{2}$ Sequencing showed at least six different mutations in the gene that result in familial adenomatous polyposis. ${ }^{24}$ These were either deletions of one or two base pairs or nucleotide substitutions giving a false "stop" signal during protein synthesis.

Using a similar approach, another group simultaneously came up with the same gene, ${ }^{34}$ which it showed was mutated in the germ line of patients with familial adenomatous 
polyposis but not in unaffected relatives or unrelated people. ${ }^{4}$ In some cases DNA isolated from the tumours of patients without familial adenomatous polyposis but with colorectal carcinoma also showed somatic mutations in the gene. ${ }^{4}$

How will these advances affect clinical practice? In people with a family history of familial adenomatous polyposis prenatal or postnatal testing should be able to identify whether a mutation has been inherited. This will avoid some of the problems of linkage testing which is relevant where incomplete pedigrees reduce the value of linkage analysis, which occurred in two thirds of the families reported on by MacDonald et al. ${ }^{8}$ Screening the general population for new mutations is probably impracticable because of the rarity of the condition.

The main impact of this work should be on the understanding of the pathogenesis of sporadic colorectal carcinoma, although this is more complicated. Other somatic mutations contribute to the development of sporadic colorectal cancer, ${ }^{1011}$ including the ras oncogene,${ }^{12}$ the p53 oncosuppressor gene on chromosome $17,{ }^{13}$ and the gene deleted in colon cancer on chromosome $22 .{ }^{14}$ Moreover, the effects of mutant oncosuppressor genes, including that coding for familial adenomatous polyposis, are exposed by the loss of the remaining normal version of the gene in the allelic pair. ${ }^{11} 1315$

How these genetic abnormalities fit together in the development of the tumour, what the familial adenomatous polyposis protein does in the cell, and why mutations lead to the formation of polyps are all unknown. Different inherited mutations of the gene coding for familial adenomatous polyposis are likely to be found in some people with a family history of colonic cancer (but not of adenomatous polyposis). ${ }^{16}$ Ultimately this research may offer the possibility of pre- symptomatic investigation and intervention in people with an increased risk of sporadic colonic cancer.

ANDREW J S MACPHERSON Medical Research Council Clinician Scientist INGVAR BJARNASON Senior Registrar

IAN C FORGACS Consultant Gastroenterologist

Department of Medicine and Gastroenterology,

King's College School of Medicine,

London SE5 9PJ

Joslyn G, Carlson M, Thliveris A, Albertson H, Gelbert L, Samowitz W, et al. Identification of deletion mutants and three new genes at the familial polyposis locus. Cell 1991;66:601-13.

Groden J, Thliveris A, Samowitz W, Carlson M, Gelbert L, Albertson $\mathrm{H}$, et al. Identification and characterisation of the familial adenomatous polyposis gene. Cell 1991;66:589-600.

Kinsler KW, Nilbert MC, Su L-K, Vogelstein B, Bryan TM, Levy DB, et al. Identification of FAP locus genes from chromosome 5q21. Science 1991;253:661-4.

Nishisho I, Nakamura Y, Miki Y, Ando H, Horii A, Koyama K, et al. Mutations of chromosome 5q21 genes in FAP and colorectal cancer patients. Science 1991;253:665-9.

Morson BC. The polyp cancer sequence in the large bowel. Proc $R$ Soc Med 1974:67:451-7.

6 Herrera L, Kakati S, Gibas L, Pietrzak E, Sandberg A. Brief clinical report: Gardner syndrome in a man with interstitial deletion of 5q. Am ₹ Med Genet 1986;25:473-6.

Bodmer W, Bailey C, Bodmer J, Bussey H, Ellis A, Gorman P, et al. Localisation of the gene for Bodmer W, Bailey C, Bodmer J, Bussey H, Ellis A, Gorman P, et al. Localis

MacDonald F, Morton DG, Rindl PM, Haydon J, Cullen R, Gibson J, et al. Predictive diagnosis of MacDonald F, Morton DG, Rindl PM, Haydon J, Cullen R, Gibson J, et al. Predictive diagnosis of
familial adenomatous polyposis with linked DNA markers: population based study. BMf

9 Reed TE, Neale JV. A genetic study of familial polyposis of the colon. Am $\mathcal{f}$ Hum Genet 1955;7:236-63.

10 Kinzler K, Nilbert M, Su L-K, Vogelstein B, Bryan T, Levy D, et al. Identification of a gene located at chromosome 5q21 that is mutated in colorectal cancers. Science 1991;251:1366-70.

11 Vogelstein B, Fearon ER, Hamilton SR, Kern SE, Preisinger AC, Leppert M, et al. Genetic alterations during colorectal tumour development. $N$ Engl f Med 1988;319:525-32.

2 Bos J, Fearon E, Hamilton S, Verlaan-de Vries M, van Bloom J, van der Eb AJ, et al. Prevalence of ras gene mutations in colorectal cancers. Nature 1987;327:293-7.

3 Baker SJ, Fearon E. Nigro J, Hamilton S, Preisinger A, Jessup J, et al. Chromosome 17 deletions and p53 gene mutations in colorectal cancer Science 1989;244:217-21.

14 Fearon E, Cho K, Nigro J, Kern S, Simons J, Ruppert J, et al. Identification of a chromosome $18 \mathrm{q}$ gene that is alered in , Kcience 1990:247:49-56.

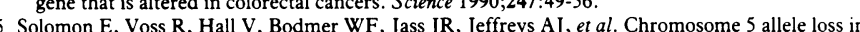
human

6 Leppert M, Burt R, Hughes JP, Samowitz W, Nakamura Y, Woodward S, et al. Genetic analysis of an inherited polymorphism to colon cancer in a family with a variable number of adenomatous polyps. N Engl F Med 1990;322:904-8.

\title{
Adjuvant treatment for breast cancer: the overview
}

\author{
Ovarian ablation, chemotherapy, and tamoxifen all work
}

Breast cancer will affect an estimated five million women in the next decade. To date, adjuvant systemic treatments have only modestly improved disease free and overall survival. But even a modest improvement would be worth while if experienced by such a large number of women.

During the past decade controversy has existed about the effects of adjuvant systemic treatment on overall survival in patients with operable breast cancer, mainly because of the small size of clinical tests. To decide which current treatments confer benefit has required collating individual data on 75000 women from 133 clinical trials. ${ }^{1}$ The overview clearly showed that adjuvant treatment with ovarian ablation, tamoxifen, or polychemotherapy produced benefit. Perhaps the biggest surprise was the continuously increasing survival benefit for patients more than five years after treatment with adjuvant systemic therapy.

The overview was derived exclusively from randomised clinical trials; unfortunately, only a few patients with breast cancer have been entered into such trials. To obtain adequate statistical power to refute the null hypothesis that treatment had no effect the overview therefore included trials that were not simply comparisons of a particular treatment with nontreatment. For example, the tamoxifen overview included trials comparing tamoxifen and cytotoxic drugs with cytotoxic drugs alone. Many patients included in the treatment group of each overview therefore received a more complex adjuvant treatment, only one component of which was the subject of the overview. Although legitimate statistically, ${ }^{2}$ this may have understated the size of the effect of treatment.

The evaluations of ovarian ablation, cytotoxic drugs, and tamoxifen included trials conducted at different times. Ovarian ablation was the first of these modalities tested. Although patients in these trials had the longest follow up, data on oestrogen receptors were not available when patients were entered into the trials. The earliest trials of chemotherapy evaluated single agents, sometimes given in short perioperative courses, but neither of these approaches is now considered to be optimal. More recent trials have concentrated on polychemotherapy and tamoxifen. Obviously, characteristics of the patients may have affected chosen treatments; the three overviews are therefore too different to allow direct comparison and cannot be used as the basis for deciding individual treatment.

Another important observation was the unequivocal finding of an overall survival benefit from adjuvant ovarian ablation in younger women. This procedure has been virtually abandoned during the past decade on the assumption that its benefit was limited to delaying recurrence. But problems remain in determining its proper use: the results apply only to women under 50 years old and its side effects in this group 